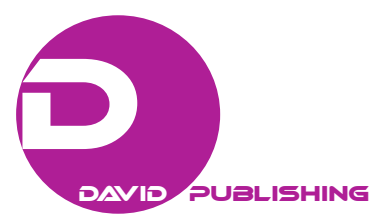

\title{
Review on Non-Formal Education Practices in Vietnam
}

\author{
Chau T. M. Cao \\ Dai Nam University, Hanoi, Vietnam
}

\begin{abstract}
It has been a long argument about the efficiency of non-formal education (NFE) regarding the plan to achieve education for all (EFA). It is undeniable that formal schooling plays the main roles to increase the primary education rate and is often believed to be the most effective method to achieve universal primary school. However, NFE becomes a vital part of education system to the population that is neglected by the education, then look at NFE practices in developing countries, and finally, review the situation in Vietnam.
\end{abstract}

Keywords: non-formal education (NFE), education for all (EFA), education in developing countries, Vietnamese education

\section{Introduction}

Formal schooling or mainstream schooling has been an effective method to educate people for centuries. With the ability of providing education for a large number of people, it continues to prove its role in achieving education for all (EFA). However, there is population still left behind by formal schooling, which calls for other method of education. As Osman (2005) argued, "Non-formal education (NFE), because of its diversity and flexibility, can make a special contribution to the quality of provision of education, not only just by making it available, but also accessible, acceptable, and adaptable”. Therefore, NFE with its flexibility could be a response for those neglected by mainstream education. This study would review the differences between formal education and NFE following by the situation of developing countries with the case study of Vietnam.

\section{Formal Education, NFE, and Informal Education}

There are three major types of education, including formal education, NFE, and informal education with different context, teaching pedagogies, and so on. These forms of education are briefly explained as following.

Formal education has a well-defined set of features, as Baguma and Okecho (2010, as cited in Ngaka, Openjuru, \& Mazur, 2012) defined as "the hierarchically structured, chronologically graded educational system running from primary school through to university and including, in addition to general academic studies, a variety of specialized programs and institutions for full-time technical and professional training”.

NFE, on the other hand, was described by United Nations Educational Scientific and Cultural Organization (UNESCO) (1997a, p. 14; 1997b) as "any organized and sustained educational activities that do not exactly correspond to the definition of formal education”. In other words, NFE is an educational activity that could be provided by any agencies, normally for a particular target group, especially for disadvantaged population.

Informal education refers to the unconscious process through which people acquire and accumulate experience, knowledge, skills, attitudes, and insights from daily life experiences and exposure to the 
environment (Ngaka, Openjuru, \& Mazur, 2012).

Regarding the educational policies and strategies, this paper will focus on two types of education, which are formal education and NFE. The differences between these two can be seen in Simkins (1977, pp. 12-15, as cited in Ngaka, Openjuru, \& Mazur, 2012) as shown in Table 1 below.

Table 1

Ideal Type/Models of Formal and NFE

\begin{tabular}{|l|l|l|}
\hline Differences & Formal education & NFE \\
\hline Purpose & $\begin{array}{l}\text { Long-term and general; } \\
\text { Certified. }\end{array}$ & $\begin{array}{l}\text { Short-term and specific; } \\
\text { Certificate not necessarily the main purpose. }\end{array}$ \\
\hline Timing & Long cycle/preparatory/full-time & Short cycle/recurrent/part-time \\
\hline Content & $\begin{array}{l}\text { Standardized/input centered; } \\
\text { Academic; } \\
\text { Entry requirements determine. }\end{array}$ & $\begin{array}{l}\text { Individualized/output centered; } \\
\text { Practical; } \\
\text { Clientele determine the entry clientele requirements }\end{array}$ \\
\hline Delivery system & $\begin{array}{l}\text { Institution-based isolated from environment; } \\
\text { igidly structured, teacher-centered, and resource } \\
\text { intensive. }\end{array}$ & $\begin{array}{l}\text { Environment-based and embedded in the } \\
\text { community; } \\
\text { Flexible, learner-centered, and resource efficient. }\end{array}$ \\
\hline Control & External/hierarchical & Self-governing/democratic \\
\hline
\end{tabular}

Note. Ngaka, Openjuru, and Mazur (2012) summarized from Simkins (1977, pp. 12-15, as cited in Fordham, 1993).

\section{Non-Formal Basic Education Practices in Developing Countries}

In order to achieve universal primary education, NFE plays a significant role to provide education for disadvantage population. There is one statement that came out from the Council of Europe (2000, as cited in Kamil, 2007, p. 2) that "formal educational systems alone cannot respond to the challenges of modern society, and therefore, welcomes its reinforcement by non-formal educational practices”.

There are a number of evidences that prove the effectiveness of NFE. In the following section, past researches will briefly summarize to show the result of NFE practice in the developing countries, such as in Africa and Asia.

\section{In Africa}

Most of the researches and reports have been done in African countries and showed the positive effect of NFE. From 2001 to 2007, United Nations Development Program (UNDP) joined with Malagasy government to implement a NFE program to promote EFA. Of those participants who completed the four phases of basic literacy training during the initial stages of the program, 76.4\% obtained the minimal level of skill in literacy (after 48 days of effective literacy), while 35.5\% acquired the advanced level (UNESCO, 2008). Uganda has similarly achieved considerable progress in the provision of both formal education and NFE (Ngaka, 2005, as cited in Ngaka, Openjuru, \& Mazur, 2012).

It was also an increasing number in enrollment rate in NFE school in the late 1990s in Kenya. Thompson (2001) estimated that there are over 6,000 non-formal schools and centers in Kenya catering to the learning needs of some 4.2 million children, youths, and adults. He also noted that there were 373 registered community schools in Zambia as at May, 2000 catering to the needs of 47,276 children, while the number of basic schools in Zambia was 4,000 with an enrollment of 1,617,558 pupils (2001, p. 18). Ouma (2004) also argued that NFE is a necessary alternative of mainstream to get street children to school to improve life quality in Kenya.

Interestingly, an opportunity to integrate formal education and NFE can be seen in several programs as Thompson (2001) summarized. For instance, the basic education in urban poverty areas aimed to improve the 
life perspectives of out-of-school students among the ages of 9-18 from selected suburbs of Kampala, Uganda. Although thorough researches on these cases are limited, Ngaka, Openjuru, and Mazur (2012) suggested that formal education and NFE could be integrated and attempts could be made to document and compare such learning with the one that takes place in a formal setting.

\section{In Asia}

The evaluation on NFE in Asia is not much different from Africa. One popular approach is providing education for out-of-school students resulted by child labor, poverty, and other socioeconomic background. Sud (2010) concluded that NFE for working children in Punjab, India serves a useful function in helping poor children attend school, regardless of their labor status. Also, in India, National Institute for Open Schooling witnessed increasing enrollment rates year on year, with 186,000 in 2000/2001 and 419,000 in 2009/2010 (Morpeth \& Creed, 2012).

One good case practice worth mentioning is BRAC, a Bangladesh-Based Organization founded in the year of 1972. It now has reached out for six countries and provided schooling for more than 900,000 out-of-school students (BRAC, 2014). BRAC has impressive success rates being 97\% and 99.54\% in the year of 2009 and in the year of 2010 respectively, well ahead of the country average rate (BRAC, 2012). It should be noted that according to BRAC, $90 \%$ of its students could transfer from its schools to the formal system. In addition, Bangladesh government recently has recognized the attainment and achievement of BRAC students, giving the evidence of the close formal education and NFE integration.

Terakoya movement, which was initiated by National Federation of UNESCO Associations in Japan, has achieved fruitfully in Cambodia. From 1994 to 2003, CLCs were established, providing opportunities to learn and receive vocational training in handicrafts for approximately 36,900 people (Kawakami, 2010).

Another noticeable trend in Southeast Asia is to tackle the problem of vernaculars in education, especially in Thailand, Laos, and Cambodia. A study conducted by Lee, Watt, and Frawley (2014) suggested that bilingual education using first language instruction was beneficial for the minority students in terms of mathematics achievement. Escott (2000) claimed that minority ethnic groups preferred NFE due to its local operation, language, and adaptive curriculum. In Thailand, there are 8,605 community learning centers, 7,475 NFE facilitators, 759 highland CLCs in the mountainous areas, and 1,174 NFE facilitators. Catering education needs for remote village members and minority ethnic groups (Leowarin, 2010).

Following the same approach, Highland Children's Education Project, funded by AusAID, with supplementary funding for specific activities from the United Nations Children's Fund (UNICEF), John Martello/Tower Capital Fund, Direct Aid Program and the Canada Fund, aims to provide ethnic minority children in Ratanakiri province (Cambodia) with the first two years of primary education in their own languages, and Khmer, the national language. This innovative model of bilingual education brings learning opportunities to isolated ethnic groups in their mother tongues and also implies the importance of having an appropriate policy to implement bilingual education nationwide (Middelborg, 2005).

\section{NFE in the Context of Vietnam}

\section{Background}

After the economic reform "Doi Moi" 1986, Vietnam had made great achievements in the field of education. The country has completed the literacy, universal primary education, and started implementing 
universal secondary education. Vietnam has a quite complete and unified national education system at all levels and provides various types of education.

Table 2

Literacy Rate ${ }^{(*)}$ of Population Over the Age of 15

\begin{tabular}{llll}
\hline Gender/Socioeconomic region & Total (\%) & Urban area (\%) & Rural area (\%) \\
\hline National & 94.2 & 97.3 & 92.7 \\
Male & 96.2 & 98.3 & 95.3 \\
Female & 92.2 & 96.4 & 90.3 \\
\hline Socioeconomic region & & & \\
\hline Northern midland and mountainous & 89.3 & 97.5 & 97.5 \\
Red river delta & 97.6 & 99.0 & 97.0 \\
Northern central and central coastal & 93.9 & 96.9 & 88.6 \\
Central highland & 90.8 & 95.8 & 95.3 \\
Southeast region & 96.7 & 97.6 & 91.5 \\
Mekong river delta & 92.3 & 94.9 & \\
\hline
\end{tabular}

Notes. ( $\left.{ }^{*}\right)$ Literacy rate is defined as to finish five years of primary education. General Statistics Office of Vietnam (GSOV), 2011.

Table 2 shows that the literacy rate of population over the age of 15 is $94.2 \%$ in 2011. Literacy rate of males is higher than females in both urban and rural areas. The figure of the Northern midland and mountainous region is the lowest, followed by the central highland, given their geographic features and diverse ethnic groups.

According to GSOV (2009), 95.9\% Kinh people (major ethnic) are literate, while only 37.7\% H'Mong people are (Northwest Vietnam ethnic). There were $40 \%$ of the minor ethnic children abdicating their right to attend elementary schools due to poverty and geographical difficulties.

The high dropout rate does not happen among rural areas only. Urban cities also face the same problem. Due to the rapid growth of metropolitans, the increasing number of migrants causes many consequences. One of them is the growing number of street children. According to Friends for Street Children Association (FFSC) (2012), there are more than 11,000 street children living in hunger and poverty in Hochiminh City. They have to work for living since the very young age and normally are abused in many ways. It is difficult for them to attend normal school in daytime

The number of out-of-school-children is quite high in some categories. Specifically, Mong and Khmer ethnicity occupy the highest proportion with $26.5 \%$ and $13.34 \%$, respectively. The rate of the out-of-school

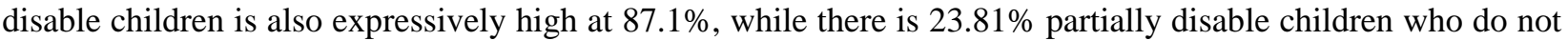
go to school (Ministry of Education and Training, 2014).

These sets of data reflect the current situation of disadvantage and vulnerable population in Vietnam, especially children. Formal education system proves to have its own limitations, which decelerate its approach to every child. Therefore, NFE becomes a key solution to achieve education for all.

\section{NFE in Vietnam}

In 2000, Vietnam adopted "Dakar Framework for Action, EFA Meeting our Collective Commitments". After that, in 2003, the government approved "National EFA Action Plan 2003-2015", setting four priority components of the education system: early childhood care and education, primary education, lower secondary education and NFE (Government of Vietnam, 2003). 
According to this plan, NFE is defined as below:

... comprises organized learning activities that cater to persons not enrolled in formal education. In Vietnam, NFE spans complementary education programmes, continuing education, and life skills development activities aimed at the different learning needs of different categories of youth and adults. NFE does not necessarily follow the structure of the formal system. It may be of varying duration, and may or may not confer certification of the learning achieved. In the EFA Plan, NFE comprises complementary primary and lower secondary programmes, life skills programmes and literacy training. (Government of Vietnam, 2003, p. 21)

The main target of NFE in Vietnam ranges from "illiterate people and those who have just been out of illiteracy, to those who dropped out of the formal education before having acquired the basic knowledge in reading, writing, and arithmetic necessary for them to have a productive life” (Lam, 2007, p. 4). Non-formal basic education mostly targets people from 15 to 35, aims to achieve $100 \%$ literate rate in the major cities and 98\% in other parts. Major problems include the quality of the education (infrastructure, teacher quality, drop-out rate, etc.) and language issue (among ethnic community).

Specific access targets for NFE include:

1. Achievements of literacy campaigns consolidated with emphasis on young illiterate adults (aged 15-34) and women;

2. 50\% of all communes have a CLC by $2005 ; 90 \%$ by 2010 and all communes by 2015;

3. Out of school children aged 6-14 (30\% by 2005 and 75\% by 2015) attend complementary primary programs;

4. Out-of-school youth aged 11-14 (30\% by 2005 and 75\% by 2015) attend complementary lower secondary programs.

Quality and relevance targets for NFE include:

1. Curriculum and textbooks of complementary primary and lower secondary programs improved;

2. Post-literacy and life skill programs diversified to meet the needs of local population by providing sufficient funds to develop and implement lifelong learning programs (\$5,000/CLC by 2015);

3. Continuing Education Centers (CEC) set up in all districts and developing localized materials and training programs.

Management targets for NFE include: Management of Continuing (CE) education and NFE reformed and modernized at every level (Government of Vietnam, 2003).

This plan has been a success in cooperating government, international organizations, bilateral donors, Non-Governmental Organization (NGOs), and civil society to ensure the quality of EFA. At the end of school year 2013-2014, literacy rate reached 98.25\% (Ministry of Education and Training, 2014).

Since 2003, numerous NFE activities have been carried out, for examples, illiteracy eradication and post-literacy programs, complementary primary and lower secondary education programs and life skills and community development programs. Those programs are supported out partly by the implementation of CLCs and continuing education centers. As CLCs at district level cannot provide learning opportunities for all, especially those who live in remote, mountainous, and rural areas, CLCs proved to be a suitable model and had been gradually established and operated in mountainous rural areas in Vietnam since 1998 (Ministry of Education and Training [MOET], 1999, as cited in Lam, 2007). By June 2006, there have been 7,384 CLCs locating nearly $70 \%$ of communes all over the country. 
“National EFA Action Plan 2003-2015” listed several action programs in target group of NFE, including "expansion of literacy and post-literacy programs for adults under age 40, prioritizing minor ethnic groups and women” (Government of Vietnam, 2003, p. 66). According to this, in 2013, Vietnamese government approved an action plan to increase the literacy rate among minor ethnic groups, targeting a literacy rate of $90 \%$ for this population in 2020. NFE, particularly CLCs continue to play a key role in this plan (Government of Vietnam, 2013).

\section{International Cooperation in NFE in Vietnam}

In Vietnam, efforts have been made to provide NFE opportunities, through CLCs, run and managed by community people. This initiative has been implemented since 1997 in Vietnam, with support from the National Federation of UNESCO Associations in Japan (NFUAJ) and UNESCO Bangkok office.

Japan International Cooperation Agency (JICA) is one of the pioneers in supporting basic education, as it is "not only contributes toward economic development, but also is the means to acquire the necessary knowledge and to develop one's ability to fully exploit the potentials to lead a quality life in the society ... also closely related to other development sector concerned” (JICA 2005). From 2003 to 2005, JICA, in cooperation with NFUAJ, supported "Project for Promotion of CLCs in the Northern Mountainous Region”, provided NFE for local villagers, particularly adult illiterates and primary school dropouts (NFUAJ, 2005).

A project entitled "Transforming Schools into Learning Centers", by Southeast Asian Ministers of Education Organization Regional Training Centre in Vietnam in cooperation with the Department of Education and Training of Ho Chi Minh City, aim to facilitate access to education for all and to promote lifelong learning in Vietnam. The project is expected to improve socioeconomic livings for members of the community, develop human resources, and succeed in the country's process of industrialization and modernization (Southeast Asian Ministers of Education Organization [SEAMEO], Regional Training Center [RETRAC], \& DOET, 2006, as cited in Lam, 2007).

UNESCO has been working closely with MOET to:

1. support the Continuing Education Department and the NFE Research Centre under VNIES to develop a set of criteria and procedures for assessing effectiveness of nearly 11,000 CLCs throughout the country;

2. support the planning and implementation of the to enhance the quality and relevance of education at all levels, from pre-primary to higher education and NFE;

3. reorient formal education and NFE according to implementation of the United Nations Decade of Education for Sustainable Development (2005-2014) (UNESCO Vietnam, 2012).

\section{Threats and Opportunities of NFE in Vietnam}

Vietnam faces the same problem with Thailand, Laos, and Cambodia regarding the large number of ethnicities, leading to the diverse languages in the country. There are 53 minor ethnicities with more than 50 spoken languages and 30 written languages, which is threatened to be extinct. In order to address this population, while the curriculum and education system could not change quickly enough, NFE could be considered a solution. Eight bilingual education systems have been implemented in selected areas as well as CLCs provide education for adults and dropouts.

Non-formal sector contributes significantly to the education achievements of Vietnam. However, the quality issue is also concerned, especially in higher education. Since the first non-formal undergraduate 
programs were launched in the early 1990s, the non-formal sector has expanded from some 217,000 students in 1999 (24\% of all tertiary students) to just fewer than 600,000 in 2006 (39\% of the total) (Lam, 2007). With low quality, depreciated degrees and lack of interest from both lecturers and learners, the graduation failure rate in non-formal programs is high. According to the MOET (2008), the failure rate was nearly $50 \%$ among the 153 higher education institutions in 2007. Notably, the figure at the University of Information Technology in Ho Chi Minh City was around 80\% and at Hanoi University it was 93\%.

A study by Handa et al. (2009) conducted in Nicaragua shows an encouraging result of the learning and development impacts of a non-formal basic education program targeted to adolescents and adults. It opens an opportunity to further develop the NFE in developing countries as a rather economical and effective method of achieving education for all. The policy of life-long learning has promising result if being conducted well.

As Thompson (2001, as cited in Ngaka, Openjuru, \& Mazur, 2012) suggested that the integration between formal education and NFE could help:

(a) address the contradictions and distortions in macro-economic situations;

(b) bring about equity in participation in development programs, thereby, helping to reduce the severe disparities in standards of living between the "haves" and "have nots";

(c) address the challenges brought about by internal armed conflicts and internal displacement of persons;

(d) quickly reach different communities with strategies for mitigating the undesirable consequences of the on-going HIV/AIDS pandemic;

(e) educate communities on the impending environmental impacts of climate change;

(f) meet the diverse educational needs of multi-cultural and post-modern societies (du Boi-Reymond, 2003, as cited in Ngaka, Openjuru, \& Mazur, 2012, p. 116);

(g) ensure cost-effective educational service delivery;

(h) assist in poverty reduction efforts;

(i) enable the beneficiaries to receive holistic training (Tavola, 2000, as cited in Ngaka, Openjuru, \& Mazur, 2012, p. 116).

Hence, it is necessary not to separate formal education and NFE in the context of education development in particular and socioeconomic development in general. The mobility of learners between two systems should increase or ideally, there should not be any distinctions at all.

The alarming data on out-of-school children with disabilities shows that there must be a timely strategy to accommodate the need of education. Segregated or special school could be a solution, because access to NFE is often only possible facilitated by non-governmental sectors, receiving personnel and special courses designed for students with disabilities.

NFE should be focused to provide literary education and combined with skill training. Given the large number of children with special needs and the limited resources available for them, "the best option is to involve the NGOs along with local level committees and also to work in collaboration with various government schemes launched by government for the benefit of the disabled children as NGOs have a propensity to work in small locations, achieving impact on the ground as compared to the government services that usually address the needs of a majority with little attention given to members of civil society, who have no choice" (Singh \& Sethi, 2015). 


\section{Conclusions}

Access to basic education is a basic human right and its accomplishment is normally the keystone of the poverty reduction strategy of developing countries. Vietnam has done a very good job by achieving universal primary, heading towards universal secondary education. However, it does not mean that the government could neglect disadvantage population, especially children and women in rural areas from minor ethnic groups and disable people.

Moreover, formal education and NFE is complementary and interdependent, formal education builds on the NFE. Meanwhile, NFE is partially taken place after formal education to ensure the life-long learning. It is recommended that the government should learn from and implement good case practices, integrate formal and NFE in order to achieve education for all, as well as cooperate with non-governmental sectors to enhance the education activities for people with special needs.

\section{References}

BRAC. (2012). Annual Report. Dhaka, Bangladesh.

BRAC. (2014). Annual Report. Dhaka, Bangladesh.

Committee on Culture and Education, Council of Europe. (1999). Non-Formal Education Report. Retrieved January 10, 2015, from http://assembly.coe.int/ASP/Doc/XrefViewHTML.asp?FileID=8807\&Language=en

Escott, J. (2000). Minority education in Cambodia: The case of the Khmer Loeu. Intercultural Education, 11(3), $239-251$.

Fordham, P. E. (1993). Informal, non-formal and formal education programmes. YMCA George Williams College ICE301 Lifelong Learning Unit, 2.

Friends for Street Children Association (FFSC) Vietnam. (2012). Tong Quan (Overview). Retrieved December 12, 2014, from http://www.ffscvn.org/index.php?option=com_k2\&view=item\&layout=item\&id=125\&Itemid=120\&lang=vi

General Statistics Office of Vietnam (GSOV). (2006). Dieu TraDan So Viet Nam 2006 (Household Survey 2006). Retrieved December 15, 2014, from https://www.gso.gov.vn/default.aspx?tabid=407\&idmid=4\&ItemID=6849

GSOV. (2009). Dieu Tra Dan So Viet Nam 2009 (Household Survey 2009). Retrieved December 15, 2014, from https://www.gso.gov.vn/default.aspx?tabid=596\&ItemID=9782

GSOV. (2011). Dieu Tra Dan So Viet Nam 2011 (Household Survey 2011). Retrieved December 15, 2014, from http://www.gso.gov.vn/default.aspx?tabid=512\&idmid=\&ItemID=12386

Government of Vietnam. (2003). National Education for All Action Plan 2003-2015. Hanoi, Vietnam.

Government of Vietnam. (2013). Quyetdinh: Pheduyet de an xoa mu chu den nam 2020 (Resolution: Approvement of literacy plan towards 2020). Retrieved January 3, 2015, from http://vanban.chinhphu.vn/portal/page/portal/chinhphu/hethongvanban? class_id=2\&_page=1\&mode=detail\&document_id=167095

Handa, S., Pineda, H., Esquivel, Y., Lopez, B., Gurdian, N. V., \& Regalia, F. (2009). Non-formal basic education as a development priority: Evidence from Nicaragua. Economics of Education Review, 28(4), 512-522.

Japan International Cooperation Agency (JICA). (2010). JICA's operation in education sector: Present and future. Retrieved January 5, 2015, from https://www.jica.go.jp/english/our_work/thematic_issues/education/pdf/position_papaer.pdf

JICA. (2012). JICA's approach to the millennium development goals: For inclusive and dynamic development. Tokyo, Japan.

Kamil, M. (2007). Looking again at non-formal and informal education towards a new paradigm. Center for Research in International Cooperation in Educational Development University of Tsukuba.

Kawakami, C. (2010). The Potential of Community Learning Centers in Cambodia: An approach by means of the world TERAKOYA movement. Retrieved January 4, 2015, from http://www.iiz-dvv.de/index.php?article_id=1074\&clang=1

Lam, C. (2007). UNESCO country profile prepared for the Education for All Global Monitoring Report 2008 Education for All by 2015: Will we make it? Vietnam: Non-formal education. Hanoi, Vietnam.

Lee, S., Watt, R., \& Frawley, J. (2014). Effectiveness of bilingual education in Cambodia: A longitudinal comparative case study of ethnic minority children in bilingual and monolingual schools. Compare: A Journal of Comparative and International Education, (ahead-of-print), 1-19.

Leowarin, S. (2010). Community Learning Centres in Thailand. Retrieved January 4, 2015, from http://www.iiz-dvv.de/index.php?article_id=1070\&clang=1 
Middelborg, J. (2005). Highland children's education project: A pilot project on bilingual education in Cambodia. Bangkok: UNESCO Bangkok.

Ministry of Education and Training (MOET) of Vietnam. (2008). Annual Report. Hanoi, Vietnam.

MOET of Vietnam. (2013). A global initiative on out-of-school children: Vietnam country study. UNICEF: Hanoi, Vietnam.

MOET of Vietnam (2014). Annual Report. Hanoi, Vietnam.

Morpeth, R., \& Creed, C. (2012). Reframing basic education to deliver education for all: Flexible provision and enabling frameworks. Open Learning: The Journal of Open, Distance and e-Learning, 27(3), 201-214.

National Federation of UNESCO Associations in Japan. (2005). Vienam shakaishugikyowakoku, hokukbusangakuchiikikomyunitigakushusentafukyukeikaku, jigyohokokusho (Final report: Project for promotion of community learning centers in the northern mountainous region, the Socialist Republic of Vietnam). Retrieved from the Author, 1-3-1. Ebisu, Shibuya-ku, Tokyo 150-0013, Japan).

Ngaka, W., Openjuru, G., \& Mazur, R. E. (2012). Exploring formal and non-formal education practices for integrated and diverse learning environments in Uganda. The International Journal of Diversity in Organizations, Communities and Nations, 11(6), 109-121.

Osman, A. (2005). Achieving education for all: The case for non-formal education-Report of a symposium on the implementation of alternative approaches in the context of quality education for all. Commonwealth Secretarial.

Pham, H. (2011). Vietnam: Non-formal sector faces quality crisis-University World News. Retrieved November 21, 2014, from http://www.universityworldnews.com/article.php?story=20111007130340776

Singh, M., \& Sethi, A. (2012). Role of NGOs in promotion of education of disabled-A case study of Jammu District. E-Journal of All India Associated Research, 124(212), 2.

Sud, P. (2010). Can non-formal education keep working children in school? A case study from Punjab, India. Journal of Education and Work, 23(1), 1-26.

Thompson, E. J. (2001). Successful experiences in non-formal education and alternative approaches to basic education in Africa. Retrieved from https://educationinnovations.org/research-and-evidence/successful-experiences-non-formal-education-andalternative-approaches-basic

United Nations Educational Scientific and Cultural Organization (UNESCO). (1997a). Hamburg declaration on adult learning. Hamburg: UNESCO.

UNESCO. (1997b). Educating for sustainable future: A transdisciplinary vision for concerted action. In Report of the International Conference: Education and Public Awareness for Sustainability. Thesalonikki: Greece.

UNESCO (2006). Global Monitoring Report 2007. Strong foundations: Early childhood care and education (p. 170). 2/1/UNESCO/R/07/E.

UNESCO. (2008). Education for All Global Monitoring Report 2008: Education for all by 2015. Will we make it? Oxford: Oxford University Press.

Vietnam National Commission for UNESCO and the UNESCO Office in Vietnam. (2012). Vietnam-UNESCO Joint Progress Report: Memorandum of understanding between the government of Vietnam and UNESCO. Retrieved January 6, 2015, from https://unesdoc.unesco.org/ark:/48223/pf0000222311 